\title{
Identifiksi Trauma Dampak Rob pada Anak di Kabupaten Pekalongan
}

\author{
Aida Rusmamariana \\ Universitas Muhammadiyah Pekajangan Pekalongan \\ Email : aidarusmariana@ymail.com
}

\begin{abstract}
Abstrak. Bencana selalu menimbulkan reaksi psikososial, bencana alam memiliki dampak yang sangat besar terhadap kesehatan psikologis anak termasuk gejala ketakutan, depresi, kecemasan, menyalahan diri sendiri, rasa bersalah, kehilangan minat di sekolah dan kegiatan lain, regresivitas, konsentrasi buruk dan eterpisahan, kecemasan. Tujuan penelitian ini untuk melakukan identifiksi trauma dampak rob yang terjadi pada anak. Metode penelitian dengan desain penelitian deskriptif menggunakan pendekatan survey dengan menggunakan kuesioner dalam pengumpulan data. Sampel dalam penelitian ini total sampling dengan jumlah 100 responden anak SD kelas 5 dan 6 . Hasil penelitian didapatkan tidak depresi $65 \%$ depresi ringan $29 \%$ depresi sedang $6 \%$, Kecemassm sedang $93 \%$ kecemasan ringan $4 \%$. Tidak cemas $3 \%$, Tidak Stress $66 \%$, Strss ringan $29 \%$ dan stress sedang $5 \%$. Simpulan masalah kecemasan yang paling banyak dialami oleh anak korban banjir. Perlu ada penelitian lebih lanjut tentang tindakan untuk mengatasi masalah kecemasan pada anak dengan memperhatikan hak-hak anak. Kata kunci: depresi, cemas, strss, anak usia sekolah, dampak rob
\end{abstract}

\section{Identification of Traumatic Flood's Impact for Children in Pekalongan Regency}

Abstract. Disasters are always raises psychosocial reactions, and disasters have a very large impact on children's psychological health including symptoms of fear, depression, anxiety, self-blame, guilt, loss of interest in school and other activities, regressiveness, poor concentration and separation, anxiety. The purpose of this study was to identify the trauma impact of tearing that occurs in children. The research method was descriptive research design used a survey approach using a questionnaire in data collection. The sample in this study was total sampling with a total of 100 respondents of elementary school children in grades 5 and 6 . The results obtained were not depressed 65\%, mild depression 29\% and moderate depression 6\%. Moderate anxiety 93\%, mild anxiety 4\% and Normal or No anxiety 3\%. No stress 66\%, Mild Stress 29\% and Moderate Stress 5\%. The conclusion that the problem of anxiety is mostly experienced by children who are flood victims. There needs to be further research on measures to overcome anxiety problems in children by paying attention to children's rights.

Key words: Depression, anxiety, stress, School age children, the impact of flood.

\section{Pendahuluan}

Bencana alam sering terjadi di Indonesia karena alasan geografi Indonesia sehingga dapat dikatakan sebagai negara yang rawan terhadap bencana alam, salah satunya adalah banjir. Bencana alam adalah bencana yang diakibatkan oleh peristiwa atau serangkaian peristiwa yang disebabkan oleh alam antara lain berupa gempa bumi, tsuai, gunung meletus, banjir, kekeringan, angin topan da tanah longsor. Bencana tersebut dapat mengakibatkan timbulnya korban jiwa manusia, keusakan lingkungan, kerugian harta benda dan dampak psikologis.(UU RI no 24 tahun 2007). 
Salah satu bencana tersebut adalah banjir yang dapat disebabkan oleh curah hujan yang tinggi sehingga bendungan air di suatu wilayah tidak dapat menampung kemudian meluap peresapan air atau drainase di suatu wilayah yang buruk dan naiknya permukaan air laut atau sering disebut rob. Pekalongan sudah dilanda Banjir Rob lebih dari 1 dekade. Banjir Rob banyak meninggalkan persoalan dari kesehatan, pendidikan, sanitasi, sosial budaya, dan yang pasti ekonomi. Sejak tahun 2002 Pekalongan terdampak perubahan iklim secara langsung dengan adanya banjir rob, dan hingga tahun 2018 di wilayah Kota Pekalongan sudah 31\% luas wilayahnya tergenang air laut bahkan secara permanen dan terus meluas. (Salim, Siswanto, 2018)

Di wilayah Pantai Utara termasuk Kabupaten Pekalongan yang merupakan kawasan rendah yang mempunyai batas wilayah laut dengan wilayah daratan mempunyai permasalahan yang cukup tinggi karena banjir rob yang menggenangi pemukiman penduduk. Di wilayah Pekalongan baik kota maupun kabupaten Pekalongan hampir diseluruh wilayah pesisirnya mengalami masalah banjir rob tersebut. Dampak rob tersebut bukan hanya terjadi masalah pada lingkungan tetapi juga masalah psikologis dari masyarakatnya. Di wilayah Pekalongan yang terdampak rob terdapat di wilayah 5 kecamatan pada 20 Desa di Kabupaten Pekalongan termasuk desa Karangjompo Kabupaten Pekalongan.

Korban bencana sering mangalami masalah psikologis. Bencana selalu dibarengi dengan reaksi psikososial, dan penenlitian menunjukkan bahwa bencana alam memiliki dampak yang sangat besar terhadap kesehatan psikologis anak termasuk gejala ketakutan, depresi, kecemasa, menyalahan diri sendiri, rasa bersalah, kehilangan minat di sekolah dan kegiatan lain, regresivitas, konsentrasi buruk dan eterpisahan, kecemasan (Hasan, Singh, Sekar, 2018). Kondisi psikis dan mental para korban bukan hanya terjadi pada orang dewasa tetapi juga pada anak-anak. Masalah ini terjadi terutama pada daerah yang mengalami bencana berulang seperti halnya bencana rob yang terjadi di Pekalongan. Anak yang menjadi krban rob sangat rentan mempunyai masalah stress, cemas maupun Depresi.

Bencana memiliki pengaruh terbesar pada kelompok yang paling rentan terutama adalah kelompok usia anak-anak (Nakamuran, 2005). Hal ini disebabkan karena anak-anak secara langsung mengalami, merasakan dan menyaksikan dampak yang ditimbulkan akibat faktor usia yang masih belum matang.

Berdasarkan dari uraian tersebut di atas maka anak juga termasuk korban yang rentan terhadap dampak dari bencana tersebut dan perlu mendapatkan penanganan. Penelitian ini dilakukan untuk melakukan identifiksi trauma dampak rob yang terjadi pada anak yang nantinya hasil penenlitian ini dapat digunakan merencanakan tindakan penanganan masalah tersebut terhadap anak-anak perlu dilakukan identifikasi trauma dampak rob pada anak di kabupaten Pekalongan.

\section{Metode}

Desain penelitian ini menggunakan deskriptif menggunakan pendekatan survey dengan menggunakan kuesioner dalam pengumpulan data. Populasi dari penenlitan ini adalah seluruh anak-anak usia sekolah dasar yang tinggal di daerah terkena dampak rob di Kecamatan Tirto Kabupaten Pekalongan. Sampel dalam penelitian ini total sampling dengan jumlah 100 responden anak SD kelas 5 dan 6 yang ada di kecamatan Tirto kabupaten Pekalongan yang terkena dampak rob. Tekhnik pengumpulan data dengan melakukan wawancara kepada responden dengan memberikan 42 item pertanyaan. Wawancara dengan mendatangi responden di sekolah, rumah tempat tinggalnya dan di penampungan untuk responden yang tinggal di penampungan. Depresi, ansietas dan stress yang terjadi pada responden dinilai dengan menggunakan kuesioner Depression, Anxietas, Stress Scale 42 (versi 42 ) yang diberikan kepada 
responden dengan memberikan penjelasan kepad resonden dan pengumpulan data menyesuaikan dengan kondisi responden untuk bisa dilakukan wawanara

\section{Hasil Penelitian}

Hasil penelitian terhadap 100 responden adalah sebagai berikut:

1. Tabel 1. Karakteristik Resonden $\mathrm{N}=100$ )

\begin{tabular}{lcc} 
Usia (tahun) & Frekuensi & Persentase \\
\hline 9 & 4 & $4 \%$ \\
10 & 31 & $31 \%$ \\
11 & 48 & $48 \%$ \\
12 & 10 & $10 \%$ \\
13 & 7 & $7 \%$ \\
\hline \multicolumn{2}{c}{}
\end{tabular}

\begin{tabular}{|c|c|c|}
\hline Jenis Kelamin & Frekuensi & Persentase \\
\hline Perempuan & 43 & $43 \%$ \\
\hline \multirow[t]{2}{*}{ Laki-laki } & 57 & $57 \%$ \\
\hline & 100 & $100 \%$ \\
\hline \multicolumn{3}{|l|}{ Kelas } \\
\hline 5 & 32 & $32 \%$ \\
\hline \multirow[t]{2}{*}{6} & 68 & $68 \%$ \\
\hline & 100 & $100 \%$ \\
\hline Pekerjaan Orang Tua & Frekuensi & Persentase \\
\hline buruh & 73 & $73 \%$ \\
\hline wiraswasta & 22 & $22 \%$ \\
\hline nelayan & 1 & $1 \%$ \\
\hline karyawan & 2 & $2 \%$ \\
\hline perangkat desa & 1 & $1 \%$ \\
\hline \multirow[t]{2}{*}{ guru } & 1 & $1 \%$ \\
\hline & 100 & $100 \%$ \\
\hline
\end{tabular}

\begin{tabular}{lcc}
\hline Type Keluarga & Frekuensi & Persentase \\
\hline inti & 62 & $62 \%$ \\
besar & 37 & $37 \%$ \\
orangtua tunggal & 1 & $1 \%$ \\
\hline & 100 & $100 \%$ \\
\hline
\end{tabular}

\begin{tabular}{lcc}
\hline Tempat Tinggal & Frekuensi & Persentase \\
\hline rumah & 20 & $20 \%$ \\
pengungsian & 80 & $80 \%$ \\
\hline & 100 & $100 \%$
\end{tabular}

Berdasarkan tabel 1 tentang karakteristik responden berdasarkan usia hampir separo yaitu $48 \%$ berusia 11 tahun dan sebagian kecil yaitu $4 \%$ berusia 9 tahun.
Lebih dari separo responden yaitu $57 \%$ berjenis kelamin laki-laki. Sebagian besar responden yaitu $68 \%$ kelas 6 dan $32 \%$ kelas 5. Karakteristik berdasarkan pekerjaan orang tua, sebagian besar sebagai buruh yaitu $73 \%$. Sebagian besar responden yaitu $62 \%$ sebagai keluarga inti dan sebagian besar (80) responden tidak tinggal di pengungsian tetapi di rumah sendiri.

2. Tabel 2. Gambaran Depresi Trauma Dampak Rob pada anak

\begin{tabular}{ccc}
\hline Katagori & Frekuensi & Presentasi \\
\hline $\begin{array}{c}\text { Normal } \\
0-9\end{array}$ & 65 & $65 \%$ \\
$\begin{array}{c}\text { Ringan } \\
10-13\end{array}$ & 29 & $29 \%$ \\
Sedang & & \\
$14-20$ & 6 & $6 \%$ \\
\hline & 100 & $100 \%$ \\
\hline
\end{tabular}

Berdasrkan tabel 2. Didapatkan data bahawa sebagian besar dari responden yaitu $65 \%$ gambaran depresinya adalah normal, depresi ringan sebanyak $29 \%$ dan paling kecil $6 \%$ dengan katagori depresi sedang.

3. Tabel 3. Gambaran Ansietas Trauma Dampak Rob pada anak

\begin{tabular}{ccc}
\hline Katagori & Frekuensi & Presentasi \\
\hline $\begin{array}{c}\text { Normal } \\
0-7\end{array}$ & 3 & $3 \%$ \\
Ringan & & \\
$8-9$ & 4 & $4 \%$ \\
Sedang & & \\
$10-14$ & 93 & $93 \%$ \\
\hline & 100 & $100 \%$ \\
\hline
\end{tabular}

Berdasarkan dari tabel 3 tersebut diatas didapatkan data bahwa sebagian besar respon mengalami kecemasa sedang yaitu sebanyak $93 \%$ dan sebanya $4 \%$ dengan kecemasana rinngan dan $3 \%$ responden normal. 
4. Tabel 4. Gambaran Stress Trauma Dampak Rob pada anak

\begin{tabular}{ccc}
\hline Katagori & Frekuensi & Presentasi \\
\hline Normal & 66 & $66 \%$ \\
$0-14$ & & \\
Ringan & 29 & $29 \%$ \\
$15-18$ & & $5 \%$ \\
$\begin{array}{c}\text { Sedang } \\
19-25\end{array}$ & 5 & \\
\hline & 100 & $100 \%$ \\
\hline
\end{tabular}

Berdasarkan dari tabel 4 tersebut diatas didapatkan data bahwa sebagian besar yaitu $66 \%$ responden tidak mengalami stress, responden sebanak $29 \%$ dengn stress ringan dan $5 \%$ respondeng stress sedang.

\section{Pembahasan}

Dari hasil penelitian yang dilakukan terhadap 100 responden yang tinggal di penempungan sebanyak $80 \%$ dan $20 \%$ respondennya masih tinggal di rumah tempat tinggalnya.

Masalah Depresi, ansietas dan stress yang paling banyak dialami responden adalah ansietas (kecemasan) sebanyak 93\% dari 100 respon dengan katagori ansietas ringan sedangkan untuk masalah depresi lebih dari separo (65\%) dengan katagori normal. Demikian juga dengan masalah stress lebih dari separo $(66 \%)$ dengan katagori normal. Dari hasil penelitian ini didapatkan masalah anak yang mengalami bencana rob di Pekalongan, anak laki-laki lebih banyak dibandingkan dengan permepuan dan sebagian besar dari anakanak tersebut mengalami kecemasan yaitu 93\%. Hasil penelitian ini berbeda dengan penelitian yang telah dilakukan sebelumnya yaitu penelitian tentang dampak kecemasan dan gejala psikologis pada anak korban bencana gempa bumi di Lombok. Penelitian tersebut menjelaskan sebagian besar anak mengalai kecemasan dalam batas normal dan $14,89 \%$ anak termasuk dalam kecemasan klinis. Seperti halnya dalam penelitian tersebut juga menunjukkan bahwa kecemasan yang dialami tergantung juga pada usia. Dari hasil penelitian menunjukkanbahwa responden sebagian besar adalah anak SD kelas 6 yang tinggal dipenampungan, dari keluarga inti dan pekerjaan orang tua ssebagi buruh.

Hasil penelitian menunjukkan bahwa responden $80 \%$ tinggal di penampungan atau pengungsian, orang tua sebagian besar berprofesdi sebagai buruh yang tentunya dapat menjadi suatu hal menimbulkan kecemasan pada anak-anak yang tinggal penampungan karena mereka tinggal di tempat yang baru, harus menyesuaikan diri dan berbagi denngan yang lainnya yang sering tidak bersama dengan orang tuanya yang harus tetap bekerja yang bekerja sebagai buruh harian dan juga ada yang tidak bekerja orang tuannya yang bekerja sebagai buruh industri rumahan yang juga kena dampak banjir rob. Anak yang menjadi korban bancana, masalah kecemasannya tergantung dari adaptasi yang dimiliki oleh masing-masing individu. Dalam upaya membantu anak-anak yang terdampak bencana harusnya memperhatikan hak-hak mereka sebagai anak-anak yaitu Kelangsungan hidup dan perkembangan, Non Diskriminasi, Partisipasi Anak, Kepentingan terbaik bagi anak (Kemenppa)

\section{Simpulan}

Hasil dari penelitian terhadap korban rob didapatkan data dari 100 responden, yang tinggal di penampungan $80 \%$ didapatkan hasil $29 \%$ anak dengan depresi sedang, 93\% kecemasan sedang dan $5 \%$ stress sedang. Masalah kecemasan yang paling banyak dialami oleh anak korban banjir karena mereka harus menyesuaikan diri dengan lingkungan yang baru, kebiasaan baru, perubahan sikap dari keluarga. Untuk mengatasi masalah tersebut perlu ada penelitian lebih lanjut tentang tindakan untuk mengatasi masalah kecemasan pada anak dengan memperhatikan hak-hak anak. 


\section{Daftar Pustaka}

Brewin, CR, Rose S. Andrew B, Green J, Tata,P. Mc Evedy,C. Turner S, Foa EB. 2002. Brief Screening Instrument For Post-Traumatic Stress Disoder. British Journal of Psychiatritry. 181, 168-162. Dibaca 2 juli 2020. https://pubmed.ncbi.nlm.nih.gov/121512 88/

Hanifah, UN, Pratiwi A. 2020. Gambaran Kecemasan Anak dengan Post Trauma Stress Disorder Sebagai dampak Bencana Alam Angin Putting Beliung. JIKJ vol. 3 No 2. Hal 173-184, Mei 2020. Persatuan Perawat Nasional Indonesia Jawa Tengah.

Hassan, F.UI, Singh, G. Sekar,K, 2018, Children's Reactions to flood disaster In Kashmir. Indian J, Psychol Med. V40(5), September-October 2018. Dilihat 2 Juli 2020.

https://www.ncbi.nlm.nih.gov/pmc/artic $\underline{\text { les/PMC6149299/. }}$.

Kemmeerian Pemberdayaan Perempuan dan Perlindungan Anak. Dukungan Psikososial Bagi Anak Korban Bencana Alam. www.kemenpppa.go.id.

Nakamura,Y. 2005. Public Health Impact od Disaster JMAJ, 48(7).377-384

Purnama, I, 2016, Perbedaan Reaksi Anak dan Remaja Pasca Pasca Bencana, Jurnal PPKM (2016) 49-55

Salim, M.A, \&Siswanto,A.B,2018 Penanganan Banjir Dan Rob Di Wilayah Pekalongan, Jurnal Tekhnik Sipil Untag Semarang. Vol 11 tahun 2018, dilihat 2 Juli 2020 , http://jurnal.untagsmg.ac.id/index.php/j ts/article/view/789.
Thoyibah,Z, Dwiyanti M,Mulianingsih, M. Nurmayani, W. Wiguna, RI., 2019, Gambaran Dampak Kecemasan dan Gejala Psikologis pada Anak Korban Bencana Bumi di Lombok. Journal of Holistic Nursing Health Science, volume 2, Nol Juni 2019 (hal 31-38). Dilihat 2 juli 2020 https://ejournal2.undip.ac.id/index.php/ $\underline{\text { hnhs }}$ 